\title{
Internal control of transactions operation in the sustainable management system of organizations
}

\author{
Alsou Zakirova ${ }^{1, *}$, Guzaliya Klychova ${ }^{1}$, Angelina Dyatlova $^{2}$, Gamlet Ostaev $^{3}$, and Elena \\ Konina $^{3}$ \\ ${ }^{1}$ Kazan State Agrarian University, 65, Karl Marx str., 420015, Kazan, Russia \\ ${ }^{2}$ Moscow University Ministry of Internal Affairs of Russian named after V. J. Kikot, Academic \\ Volgin str., 12, 117997, Moscow, Russia \\ ${ }^{3}$ Izhevsk State Agricultural Academy, 11, Studencheskaya str., 426069, Izhevsk, Russia
}

\begin{abstract}
In modern conditions one of the main problems of economic entities is the increase in accounts receivable and payable, which is influenced by objective and subjective factors. In this connection the role of internal control of settlement operations is increasing. The aim of the article is to improve methodological support of internal control of settlement operations for increasing the quality of audit, providing information about the state of settlements with contractors to the management of enterprise for making operational and strategic management decisions. The proposed methodological support is based on stage-by-stage audit of settlement operations including the following main stages: audit planning; implementation of control procedures; execution of audit results. the peculiarity of internal control of settlement operations is determined by a variety of normative and information support of the audit. For the purpose of improvement of control procedures in the course of the study working documents of internal control have been developed. The working document «Verification of the availability of the agreement with a separate counterparty» can be used by the controller to identify errors arising in the preparation of the contract, as well as to determine the completeness and timeliness of the parties to fulfill their obligations, With the proposed in the study working document «Confirmation of the status of settlements with counterparties» can identify cases of fraud and misstatement of data contained in the financial statements. In the course of the study it was proposed to perform a point-rating assessment of debtor reliability based on a system of key indicators in the internal control process. The suggested rating estimation of counterparties will make it possible to carry out their comparative analysis and grouping as well as to identify those counterparties that have a high probability of non-payment of existing debts. The practical significance of the study lies in the possibility of using the developed approaches to determine the information base, to set the purpose and definition of control tasks, to the rational choice of control procedures, to the use of working papers in the process of internal control of settlement operations.
\end{abstract}

\footnotetext{
*Corresponding author: zakirovaar@mail.ru
} 


\section{Introduction}

For any actively functioning economic entities in modern conditions of great importance is accounting for settlements with counterparties, Improving the efficiency of settlement relations depends directly on the independence and responsibility of economic entities in the development and adoption of management decisions [1-3]. For acceptance of effective administrative decisions the effectively functioning system of information maintenance which directly depends on creation within the enterprises of system of internal control of settlement operations is necessary [4-6].

To improve the state of settlements with counterparties it is necessary to control the ratio of accounts receivable and payable [7-9]. A large amount of accounts receivable negatively affects the financial stability and causes the need to attract additional resources [10-14]. At the same time, an increase in accounts payable leads to insolvency of the economic entity, reducing the investment attractiveness 15-17].

The structure of accounts receivable and accounts payable should be taken into account during internal control.
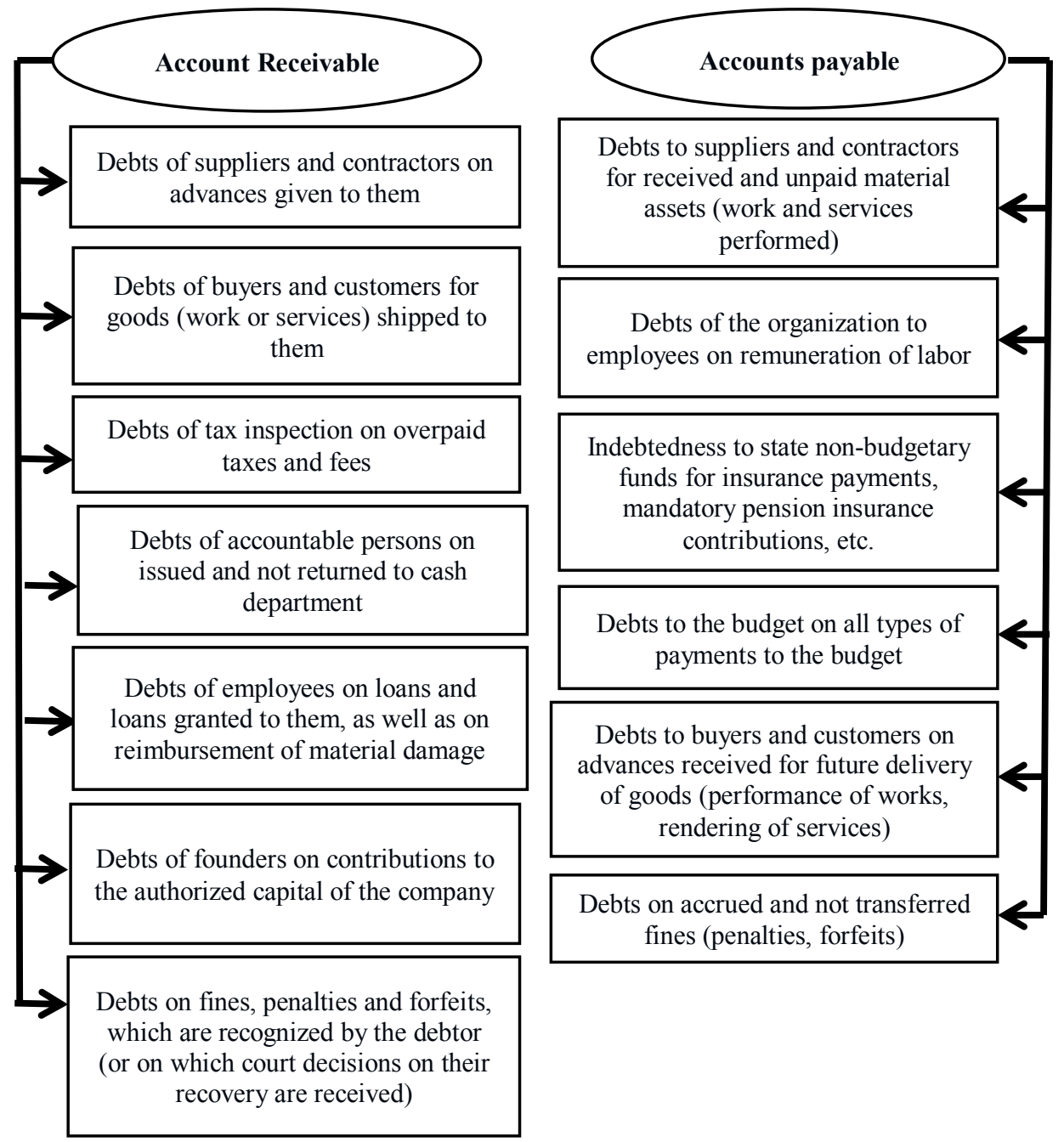

Fig. 1. Composition of accounts receivable and accounts payable. 
As can be seen from Figure 1, accounts receivable represents the amount of debts that counterparties owe to the audited economic entity. Accounts payable is represented by the indebtedness of the audited economic entity to counterparties to fulfill certain obligations.

At internal control of settlement transactions it is recommended to use a unified methodological technique, which consists in standardization of conducting an audit and implementation of control procedures [18-20]. In the most general form the process of internal control includes [21-24]:

1. Setting the goal and formulating the tasks of internal control;

2. Determination of the normative and informational support of the internal control of settlement operations.

3. Specification of the methods used in the course of control;

4. Detection of violations and formation of the conclusion on the results of inspection.

The experience of foreign authors is very useful for deepening theoretical and methodological foundations of internal control [25-28].

At the same time, the practical importance of solving the issues of optimizing the state of settlement relations with counterparties, intensified in the conditions of economic crisis, causes the need for further development of the methods of internal control of settlement operations $[29,30]$.

\section{Materials and Methods}

The purpose of internal control of settlement operations is to establish their legality, reliability and expediency, timely detection of inadmissible increase or non-payment of receivables and payables, optimization of settlement relations with counterparties, reduction of risk of arrears.

In the process of internal control of settlement operations the following tasks are solved:

- contractual and payment discipline is monitored;

- timely adjustments are made to accounting procedures with due regard for newly adopted regulations;

- the accuracy of documents recording settlement transactions is assessed;

- the reality, completeness and timeliness of the debt repayment on settlements with the contractors is confirmed;

- assessment of the correctness of the analytical accounting on the accounts of payments, check whether the data of synthetic and analytical accounting figures in the general ledger and balance sheet;

- correctness of correspondence of accounts for accounting transactions is checked;

- the periodicity of the inventory of payments in accordance with the regulations and provisions of accounting policies is determined, the results of the inventory are analyzed;

- correctness of tax calculations and timeliness of payments is assessed;

- the validity of claims made as a result of breach of contractual obligations is analyzed;

- the causes of accounts receivable and payable are established;

- the management bodies are provided with the information necessary to make effective managerial decisions;

- it is determined how effectives are the measures taken by the economic entity to minimize accounts receivable and liquidate accounts payable [31-33].

In order to assess the legality and validity of settlement transactions, as well as to solve other internal control tasks, the controller must be fully provided with the regulatory and informational framework that governs the object of inspection (Figure 2). 


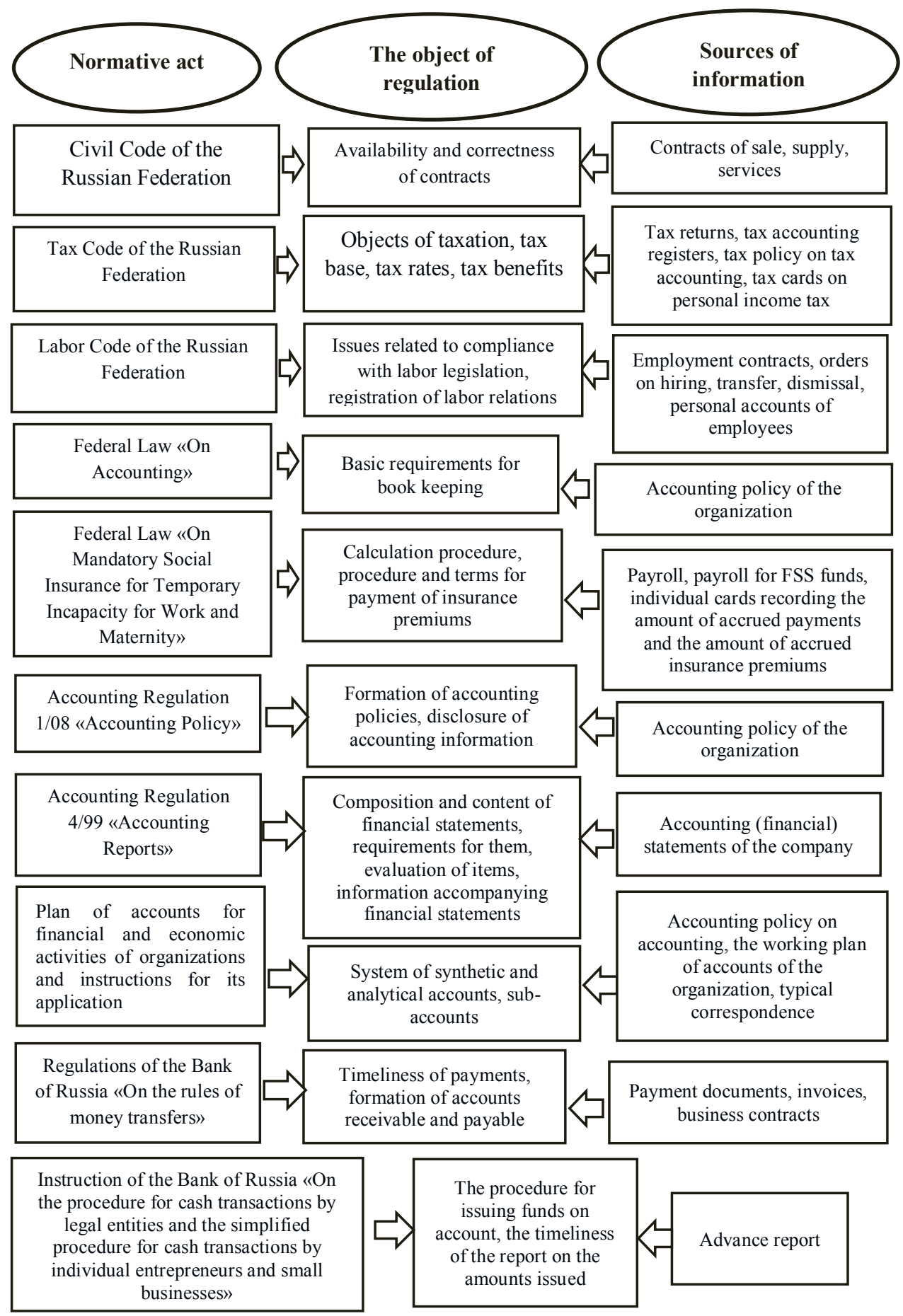

Fig. 2. Regulatory and information support of internal control of settlement transactions.

Figure 2 shows the regulatory and legal acts and sources of information that are used by the controller in the process of checking settlement transactions. Internal sources of information necessary for checking of settlement transactions are enterprise accounting 
policy, economic contracts, employment contracts, orders, administrative documents, accounting documents (invoices, bills of lading, payroll, payment documents, advance reports, registers of synthetic and analytical accounting, general ledger, etc.), reporting, tax accounting registers, tax declarations.

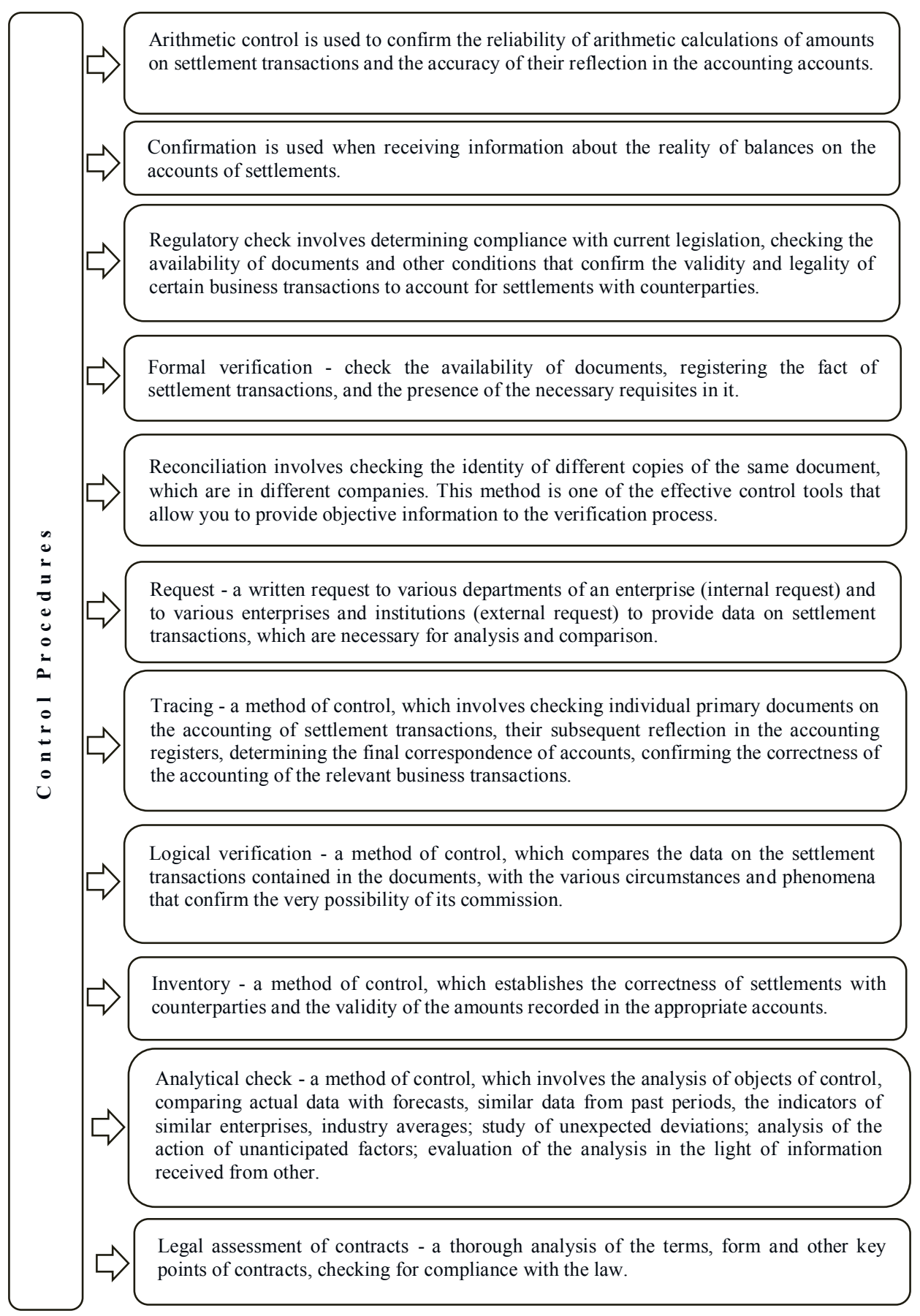

Fig. 3. Control procedures during internal control of settlement transactions. 
The efficiency of internal control is influenced by the correct application of audit methods and their interaction with the tasks that should be performed to achieve the purpose of the audit. To increase the efficiency of control at the same time reducing the time to conduct it, it is necessary to develop its clear methodology, defining control procedures in the planning of internal control.

Internal control of settlement transactions uses control procedures shown in Figure 3.

The use of control procedures presented in Figure 3 will increase the effectiveness of control, to achieve the desired results of the audit, to observe the rights and legitimate interests of controlled entities and ensure the normal functioning of the economic entity.

\section{Results}

The internal control of settlement operations includes the following main stages: planning of inspection; execution of control procedures; execution of inspection results.

An independent and obligatory stage is the planning of internal control of settlement operations in the course of which the information is obtained that allows to form an objective opinion on the reliability of accounting of settlement operations. At planning of internal control the program of internal control is made. The recommended form of the internal control working document (ICWD) «Internal Control Program of Settlement Transactions» is presented in Table 1.

Table 1. ICWD «Internal Control Program of Settlement Transactions».

\begin{tabular}{|c|c|c|c|c|c|c|}
\hline 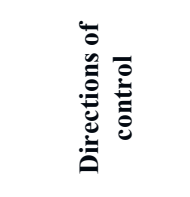 & 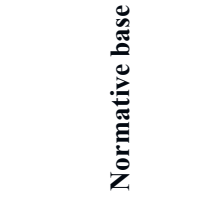 & 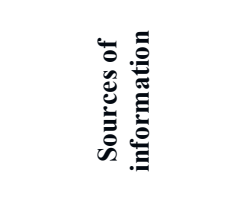 & 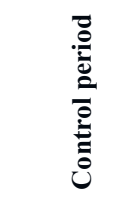 & 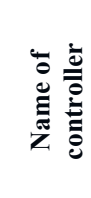 & 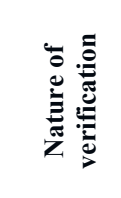 & 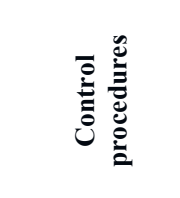 \\
\hline $\begin{array}{l}\text { 1. Assessment } \\
\text { of the } \\
\text { correctness of } \\
\text { the execution } \\
\text { of contracts }\end{array}$ & $\begin{array}{l}\text { Civil Code of the } \\
\text { Russian } \\
\text { Federation }\end{array}$ & Economic contract & 17.02 .2020 & $\begin{array}{l}\text { Ivanov } \\
\text { I.I. }\end{array}$ & Selective & $\begin{array}{l}\text { Regulatory } \\
\text { review, formal } \\
\text { verification, } \\
\text { legal } \\
\text { evaluation of } \\
\text { the contract }\end{array}$ \\
\hline $\begin{array}{l}\text { 2. Checking } \\
\text { the primary } \\
\text { accounting of } \\
\text { settlement } \\
\text { transactions }\end{array}$ & $\begin{array}{l}\text { Federal Law «On } \\
\text { Accounting» }\end{array}$ & $\begin{array}{l}\text { Invoices, } \\
\text { consignment } \\
\text { notes, payment } \\
\text { documents; forms } \\
\text { of primary } \\
\text { accounting } \\
\text { documents on } \\
\text { settlement } \\
\text { operations, } \\
\text { attached to the } \\
\text { order on } \\
\text { accounting policy } \\
\text { of } \\
\text { organization, } \\
\text { schedule } \\
\text { document flow }\end{array}$ & $\begin{array}{l}18-20.02 . \\
2020\end{array}$ & $\begin{array}{l}\text { Ivanov } \\
\text { I.I. }\end{array}$ & Selective & $\begin{array}{l}\text { Normative } \\
\text { verification, } \\
\text { formal } \\
\text { verification, } \\
\text { logical } \\
\text { verification }\end{array}$ \\
\hline $\begin{array}{l}3 . \text { Checking } \\
\text { the data } \\
\text { contained in } \\
\text { the registers of } \\
\text { accounting } \\
\text { transactions, } \\
\text { reconciliation }\end{array}$ & $\begin{array}{l}\text { Accounting } \\
\text { Regulation } 4 / 99 \\
\text { «Accounting } \\
\text { Reports», Plan of } \\
\text { accounts for } \\
\text { financial and } \\
\text { economic }\end{array}$ & $\begin{array}{l}\text { Registers of } \\
\text { synthetic and } \\
\text { analytical } \\
\text { accounting, } \\
\text { General Ledger, } \\
\text { the working plan } \\
\text { of accounts of the }\end{array}$ & 21.02 .2020 & $\begin{array}{l}\text { Ivanov } \\
\text { I.I. }\end{array}$ & selective & $\begin{array}{l}\text { Tracing, } \\
\text { arithmetic } \\
\text { check, } \\
\text { confirmation, } \\
\text { formal check }\end{array}$ \\
\hline
\end{tabular}




\begin{tabular}{|c|c|c|c|c|c|c|}
\hline $\begin{array}{l}\text { with the } \\
\text { accounts in the } \\
\text { General Ledger }\end{array}$ & $\begin{array}{l}\text { activities of } \\
\text { organizations and } \\
\text { instructions for } \\
\text { its application }\end{array}$ & $\begin{array}{ll}\text { organization, the } \\
\text { technology } \\
\text { processing } \\
\text { accounting } \\
\text { information }\end{array}$ & & & & \\
\hline $\begin{array}{l}\text { 4. Verification } \\
\text { of claims } \\
\text { settlement }\end{array}$ & $\begin{array}{l}\text { Civil Code of the } \\
\text { Russian } \\
\text { Federation, } \\
\text { Accounting } \\
\text { Regulation } 9 / 99 \\
\text { «Income of the } \\
\text { organization», } \\
\text { Accounting } \\
\text { Regulation 10/99 } \\
\text { «Expenses of the } \\
\text { organization» }\end{array}$ & $\begin{array}{lr}\text { Business } & \text { contract, } \\
\text { claims } & \text { acts, } \\
\text { accounting } & \\
\text { registers } & \end{array}$ & $\begin{array}{l}25.02 . \\
2020\end{array}$ & $\begin{array}{l}\text { Ivanov } \\
\text { I.I. }\end{array}$ & Solid & $\begin{array}{l}\text { Normative } \\
\text { verification, } \\
\text { arithmetic } \\
\text { verification, } \\
\text { inquiry, } \\
\text { formal } \\
\text { verification }\end{array}$ \\
\hline $\begin{array}{l}\text { 5. Analysis of } \\
\text { the results of } \\
\text { the settlement } \\
\text { inventory }\end{array}$ & $\begin{array}{l}\text { Methodical } \\
\text { instructions on } \\
\text { the inventory of } \\
\text { property and } \\
\text { financial } \\
\text { liabilities. Order } \\
\text { of the Ministry of } \\
\text { Finance of the } \\
\text { Russian } \\
\text { Federation of } \\
13.06 .1995 \text { г. № } \\
49\end{array}$ & $\begin{array}{lr}\text { Inventory } & \text { sheets, } \\
\text { checklists, Plan of } \\
\text { inventory } \\
\text { property } \\
\text { liabilities }\end{array}$ & $\begin{array}{l}26-27.02 . \\
2020\end{array}$ & $\begin{array}{l}\text { Ivanov } \\
\text { I.I. }\end{array}$ & Solid & $\begin{array}{l}\text { Inventory, } \\
\text { arithmetical } \\
\text { check }\end{array}$ \\
\hline $\begin{array}{l}6 . \quad \text { Checking } \\
\text { correctness of } \\
\text { correspondence } \\
\text { of accounts for } \\
\text { accounting of } \\
\text { settlement } \\
\text { transactions }\end{array}$ & $\begin{array}{l}\text { Plan of accounts } \\
\text { for financial and } \\
\text { economic } \\
\text { activities of } \\
\text { organizations and } \\
\text { instructions for } \\
\text { its application }\end{array}$ & $\begin{array}{l}\text { Registers of } \\
\text { synthetic and } \\
\text { analytical } \\
\text { accounting, } \\
\text { General Ledger, } \\
\text { chart of accounts, } \\
\text { standard } \\
\text { correspondence of } \\
\text { accounts }\end{array}$ & $\begin{array}{l}28.02 . \\
2020\end{array}$ & $\begin{array}{l}\text { Ivanov } \\
\text { I.I. }\end{array}$ & selective & $\begin{array}{l}\text { Tracking, } \\
\text { arithmetic } \\
\text { control, } \\
\text { inspection }\end{array}$ \\
\hline $\begin{array}{l}7 . \quad \text { Checking } \\
\text { the reality of } \\
\text { settlements } \\
\text { with } \\
\text { counterparties }\end{array}$ & $\begin{array}{l}\text { Civil Code of the } \\
\text { Russian } \\
\text { Federation; } \\
\text { Methodical } \\
\text { instructions on } \\
\text { the inventory of } \\
\text { property and } \\
\text { financial } \\
\text { liabilities. Order } \\
\text { of the Ministry of } \\
\text { Finance of the } \\
\text { Russian } \\
\text { Federation of } \\
13.06 .1995 \text { г. № } \\
49\end{array}$ & $\begin{array}{l}\text { Business contract, } \\
\text { invoice, } \\
\text { consignment note } \\
\text { and other primary } \\
\text { documents, } \\
\text { inventory results }\end{array}$ & $\begin{array}{l}02.03 . \\
2020\end{array}$ & $\begin{array}{l}\text { Ivanov } \\
\text { I.I. }\end{array}$ & selective & $\begin{array}{l}\text { Request, } \\
\text { confirmation, } \\
\text { inventory, } \\
\text { reconciliation }\end{array}$ \\
\hline $\begin{array}{l}\text { 8. Checking } \\
\text { the correctness } \\
\text { of tax } \\
\text { accounting of } \\
\text { settlements } \\
\text { with } \\
\text { counterparties }\end{array}$ & $\begin{array}{l}\text { Tax Code of the } \\
\text { Russian } \\
\text { Federation }\end{array}$ & $\begin{array}{lr}\text { Business } & \text { contract, } \\
\text { invoice, } & \text { tax } \\
\text { registers, } & \text { Tax } \\
\text { Accounting } & \text { Policy }\end{array}$ & $\begin{array}{l}03.02 . \\
2020\end{array}$ & $\begin{array}{l}\text { Ivanov } \\
\text { I.I. }\end{array}$ & selective & $\begin{array}{l}\text { Formal } \\
\text { verification, } \\
\text { arithmetic } \\
\text { verification, } \\
\text { confirmation }\end{array}$ \\
\hline
\end{tabular}


The peculiarity of this program is that it contains a list of control areas, regulatory basis and sources of information, defines the nature of the audit and control procedures, which are necessary to achieve the purpose and practical solution of the audit tasks.

The internal control program contains the list of control directions, regulatory basis and information sources, defines the character of control and control procedures that are necessary to achieve the purpose and practical solution of the audit tasks. The proposed program is a detailed inspection instruction and a means of quality control. The internal control program may be revised as the audit environment and the results of the control procedures change. Having approved the internal control program, you should proceed to the check of settlements with counterparties.

The technique of the internal control of the settlement operations includes the following stages.

The first stage of internal control involves the study of forms of settlements with counterparties and implementation of legal assessment of contracts for their compliance with current legislation.

During the analysis of settlements with counterparties on the basis of data in the general ledger determined by the forms of settlements with counterparties used in the enterprise (in the case of cash settlements accounts $60,62,76$, etc. are debited in correlation with credit account 51; for cash settlements - with credit account 50).

The basis of the relationship between an economic entity and counterparties are contracts, which determine the legal nature of the settlement relationship.

First of all, the controller checks the availability of contracts with individual counterparties. To do this on the basis of registers of analytical accounting counterparties with which the economic entity performs calculations for the audited period are determined. Then the names of counterparties are compared with the existing business contracts. The results of this check can be issued by the working document of internal control (table 2).

Table 2. ICWD «Verification of the availability of the agreement with a separate counterparty».

\begin{tabular}{|c|c|c|c|c|c|}
\hline $\begin{array}{c}\text { No } \\
\mathbf{p} / \mathbf{p}\end{array}$ & $\begin{array}{c}\text { Name of the } \\
\text { counterparty } \\
\text { according to } \\
\text { the analytical } \\
\text { accounting data }\end{array}$ & $\begin{array}{c}\text { Existence and } \\
\text { type of } \\
\text { contract }\end{array}$ & $\begin{array}{c}\text { Contract } \\
\text { number and } \\
\text { date }\end{array}$ & $\begin{array}{c}\text { Amount } \\
\text { under the } \\
\text { contract, } \\
\text { rubles. }\end{array}$ & $\begin{array}{c}\text { Name of } \\
\text { materials, works } \\
\text { and services } \\
\text { under the } \\
\text { contract }\end{array}$ \\
\hline 1. & LLC «Alliance» & $\begin{array}{c}\text { Contract of } \\
\text { purchase and } \\
\text { sale }\end{array}$ & $\begin{array}{c}\text { № } 1987 \text { from } \\
04.09 .2019\end{array}$ & 98000 & $\begin{array}{c}\text { Construction } \\
\text { materials }\end{array}$ \\
\hline 2. & LLC «Legion» & Work contract & $\begin{array}{c}\text { № } 1987 \text { from } \\
06.10 .2019\end{array}$ & 141000 & Auto repair shop \\
\hline 4. & LLC «Tax» & $\begin{array}{c}\text { Agreement for } \\
\text { the rendering } \\
\text { of paid } \\
\text { services }\end{array}$ & $\begin{array}{c}\text { № } 145 \text { from } \\
17.11 .2019\end{array}$ & 25000 & $\begin{array}{c}\text { Consulting } \\
\text { services }\end{array}$ \\
\hline
\end{tabular}

The peculiarity of this working document is that it accumulates information about counterparties; about the types, numbers and dates of contracts concluded with them; the amount of transactions under the contract and the object of the contract.

This document can be used by the controller to identify errors arising in the preparation of the contract and are the basis for further improper performance of the counterparties of their contractual obligations, as well as to determine the completeness and timeliness of the parties to fulfill their obligations, at internal control should be widely used such control procedures as the legal assessment of contracts.

With the help of this control procedure can be timely revealed violations made during the drawing up and conclusion of contracts. In particular, the text of the agreement may not 
contain a decoding of the subject of the agreement; when determining the liability of the parties, disproportionate liability for non-fulfillment of contractual obligations may be determined; circumstances that are not such are indicated in the contract as force majeure, etc.

The second stage - checking the primary accounting of settlement transactions is presented in detail in figure 5. As can be seen from Figure 4 at this stage the reliability (accuracy and completeness) of the facts of settlement transactions; promptness of registration of business transactions; legality of the primary accounting documentation that formalizes settlement transactions; compliance with the schedule of document flow; accuracy and completeness of accounting documents in registers; process of document storage and organization of access to the primary accounting documentation.

The third stage involves checking the identity of the data of synthetic and analytical accounting. This check is carried out selectively to establish the completeness and accuracy of the data, which are reflected in the accounts of analytical and synthetic accounting of settlements with counterparties.

By means of arithmetic check the data of synthetic accounting with data on analytical accounts are reconciled. The final data should coincide with the balances and turnovers of analytical accounts.

In addition, at this stage, the correctness and reliability of accounts receivable and payable, reflected in the balance sheet and explanations to it, is checked. The reconciliation algorithm is shown in Figure 4.

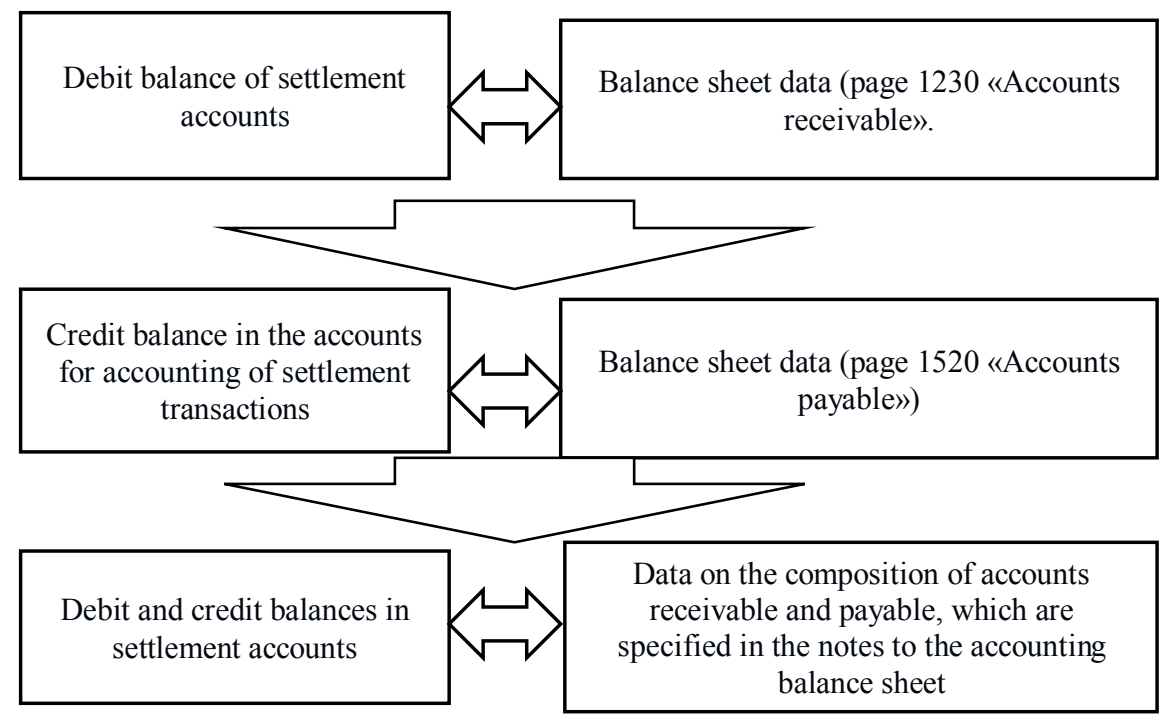

Fig. 4. Algorithm of reconciliation of the data of accounting registers with the indicators of the balance sheet. 

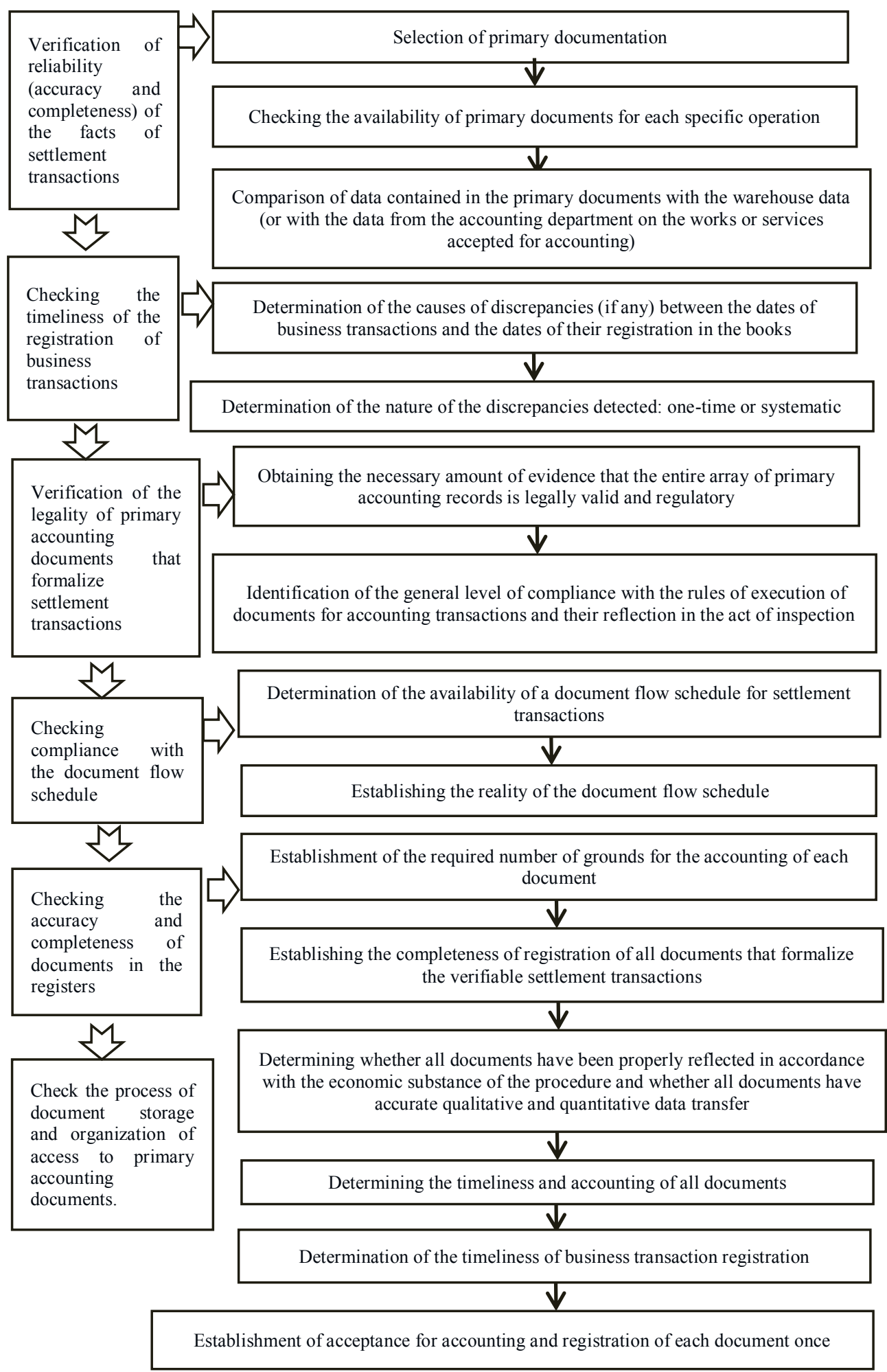

Fig. 5. Procedure for checking the primary accounting of settlement transactions. 
On the basis of registers of synthetic and analytical accounting participants of settlement relations, their number; forms of payments; directions of analytical accounting; presence of atypical accounting entries are determined.

At the fourth stage - check of settlements on claims:

1. It is defined whether the documents on pretensions arising during settlements are well grounded, timely and correctly executed; whether calculations under pretensions are correctly and completely reflected in accounting; whether debts under pretensions on the books are real; whether analytic accounting is kept for each claim;

2. The analysis of reasons of occurrence of claims; terms of arrears on claims;

3. Amounts on claims which are presented with violation of terms specified in contracts; amounts on which limitation period has expired; amounts which are not confirmed by documents are revealed.

The fifth stage of internal control of settlement transactions confirms the reality of receivables and payables resulting from settlement transactions; the correctness of organization and conduct of inventory; the validity of the results of the inventory; completeness and timeliness of the reflection of the results of the inventory.

The sixth stage implies a mandatory check on the correctness of the correspondence of accounts for each type of calculation. In particular, it is checked whether accounts receivable and payable arising during settlements with counterparties are reflected in the accounts correctly. If necessary, check individual doubtful, in the opinion of the controller, settlement transactions. Determines whether receivables and payables are properly reflected in the balance sheet.

At the seventh stage of control, the reality of settlements with debtors and creditors is checked, and confidence is achieved that the amount of accounts receivable and payable, which exist in the accounting accounts, is reflected in real amounts. This should be carried out continuous or sample inventory of settlements. In the process of such an audit the following facts are established:

- the timing of receivables and payables;

- availability of overdue accounts receivable with counterparties;

- the validity and correctness of the amounts owed for shortages and thefts that are on the balance sheet of the enterprise, as well as the measures taken to recover them;

- the presence of operations to write off bad debts, their validity and correctness;

- reality of debt repayment.

When checking the reality of settlements it is necessary to make inquiries to counterparties to obtain information about the state of settlement relations on a certain date. To confirm the state of settlements we propose to use working document «Confirmation of the status of settlements with the counterparties» (table 3).

Table 3. ICWD «Confirmation of the status of settlements with counterparties».

SECTION 1 - Reply to request from the counterparty (to be filled in by counterparty)

\begin{tabular}{|c|c|c|c|c|}
\hline \multirow{2}{*}{$\begin{array}{c}\text { Name of } \\
\text { counterparty }\end{array}$} & \multicolumn{2}{|c|}{ Bill of lading/receipt/invoice } & \multirow{2}{*}{ Total, rub. } & \begin{tabular}{c} 
Have all \\
goods/services been \\
delivered/provided as \\
of [reporting date]? \\
\cline { 2 - 3 } (yes / no)
\end{tabular} \\
\hline LLC «Alpha» & Number & Date & & Yes \\
\hline JSC «Idel» & Invoice №567840 & 05.07 .2019 & 1019672 & Yes \\
\hline
\end{tabular}


SECTION 2 - Reconciliation results (to be filled out by the controller)

\begin{tabular}{|c|c|c|l|l|}
\hline $\begin{array}{c}\text { Name of } \\
\text { counterparty }\end{array}$ & $\begin{array}{c}\text { According to } \\
\text { the request, } \\
\text { thousand } \\
\text { rubles. }\end{array}$ & $\begin{array}{c}\text { According to } \\
\text { accounting } \\
\text { data, thousand } \\
\text { rubles. }\end{array}$ & Control method & Control Results \\
\hline LLC «Alpha» & 1019672 & 1019672 & $\begin{array}{l}\text { Reconciliation, } \\
\text { inquiry, inspection, } \\
\text { confirmation }\end{array}$ & $\begin{array}{l}\text { Accounting data } \\
\text { is confirmed by } \\
\text { the counterparty }\end{array}$ \\
\hline JSC «Idel» & 546945 & 546945 & $\begin{array}{l}\text { Reconciliation, } \\
\text { inquiry, inspection, } \\
\text { confirmation }\end{array}$ & $\begin{array}{l}\text { Accounting data } \\
\text { is confirmed by } \\
\text { the counterparty }\end{array}$ \\
\hline
\end{tabular}

In the working document for counterparties, the first and second paragraphs are the amount of receivables and payables requested by the controller. This information is especially important during the audit, because the audited economic entity may intentionally overstate its accounts receivable or understate its accounts payable, and the counterparties, by responding to the inquiry letter, can help identify these violations.

By using a working document and conducting a control procedure - an inquiry to counterparties - fraud and misrepresentation in the financial statements can be detected.

The eighth stage - checking the correctness of the organization of tax accounting for settlements with counterparties includes the following areas (Figure 6).

Verification of primary documents, on the basis of which accounting records of pavments for taxes and levies were made

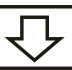

Confirmation of the correctness of the calculation of certain taxes

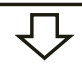

Verification of the correctness of the application of rates for various taxes and fees bv comnaring the actual rates with their values. regulated bv regulatorv documents

Checking the accuracy of accrual, completeness and timeliness of the transfer of tax payments; establishing the correctness of the allocation of taxes to their respective sources of payment

Checking the correctness of tax reporting

Fig. 6. Block diagram of checking the correctness of the organization of tax accounting of settlements with counterparties.

Based on the results of the control procedures performed, the auditor should perform the actions shown in Figure 7. 


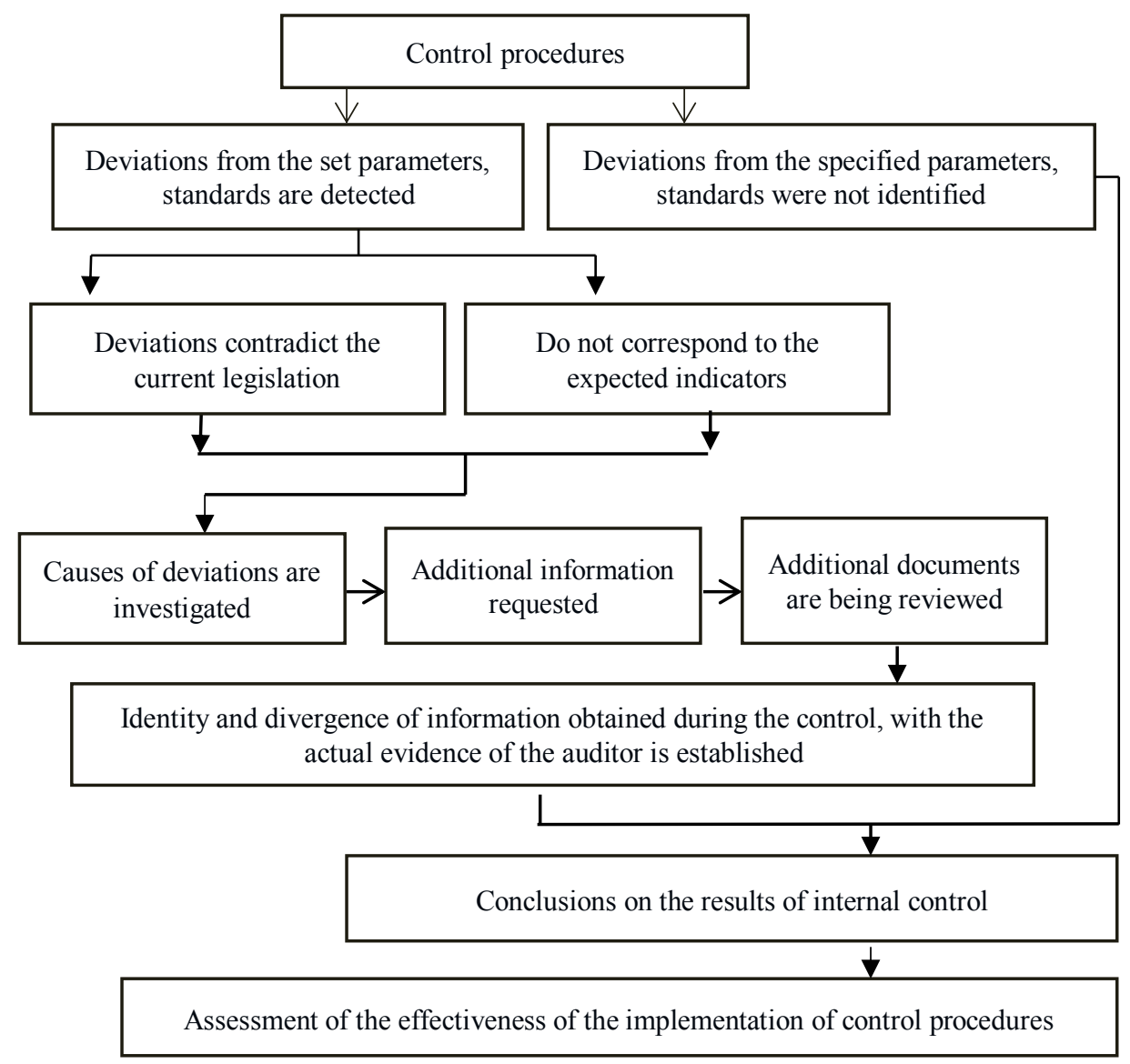

Fig. 7. Algorithm of actions of the internal controller by the results of control procedures.

In case of detection of deviations during implementation of control procedures, the reasons of deviations are investigated, reasonable conclusions on the results of internal control are formulated, as well as the evaluation of the effectiveness of implementation of control procedures is given.

To summarize the results of the audit and reflection of violations and errors detected in the course of internal control we recommend to use the working document of internal control developed by us (Table 4). This document contains a list of violations, systematized by areas of inspection and recommendations for their elimination. 
Table 4. ICWD «Identified violations in settlements with counterparties».

\begin{tabular}{|c|c|c|c|c|c|c|}
\hline 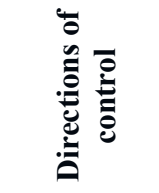 & 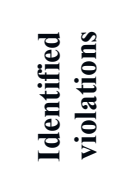 & 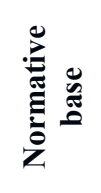 & 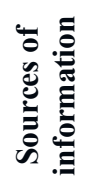 & 㝴 & 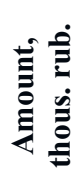 & 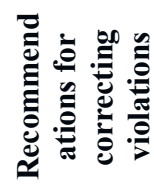 \\
\hline \multirow{3}{*}{ 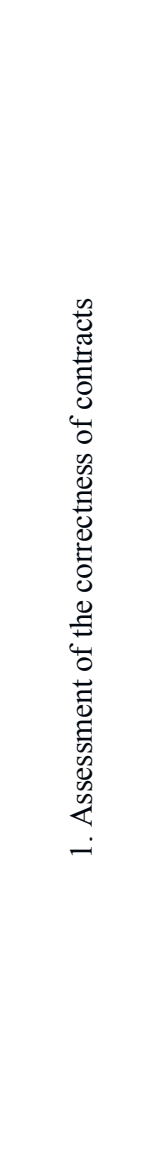 } & 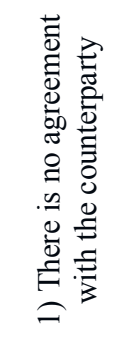 & 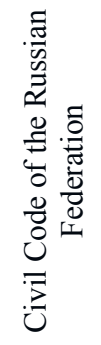 & 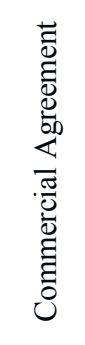 & 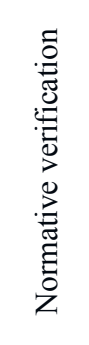 & - & 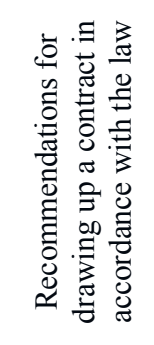 \\
\hline & 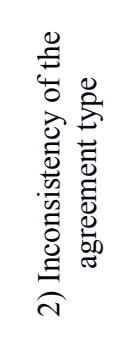 & 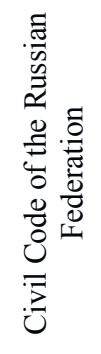 & 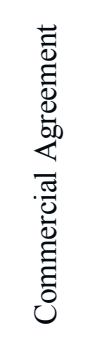 & 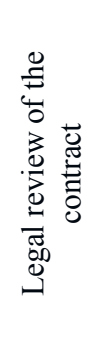 & & 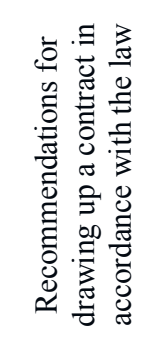 \\
\hline & 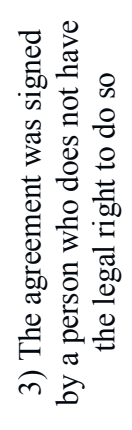 & 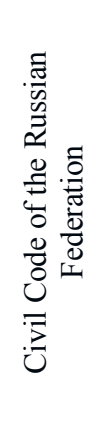 & 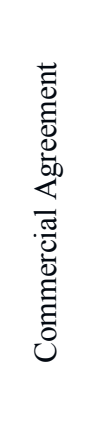 & 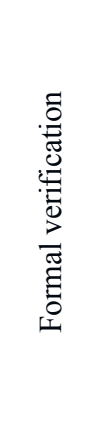 & & 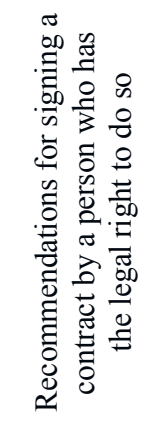 \\
\hline 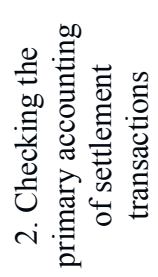 & 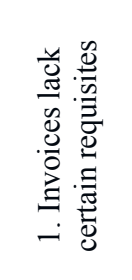 & 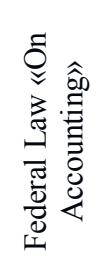 & 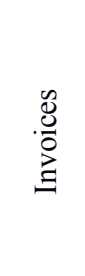 & 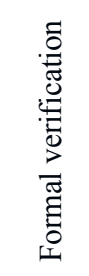 & - & 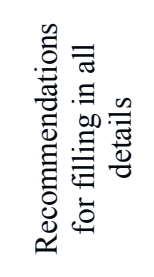 \\
\hline
\end{tabular}




\begin{tabular}{|c|c|c|c|c|c|c|}
\hline & 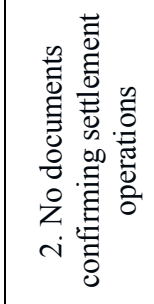 & 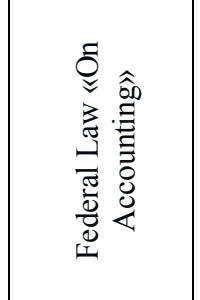 & 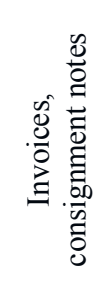 & 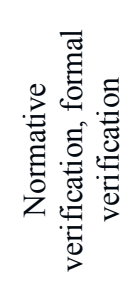 & - & 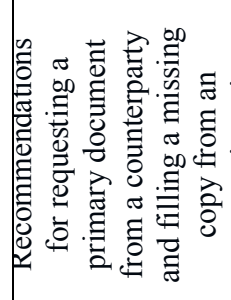 \\
\hline 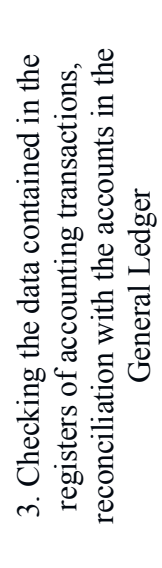 & 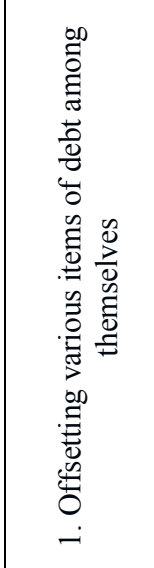 & 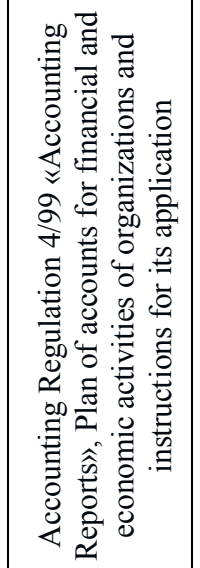 & 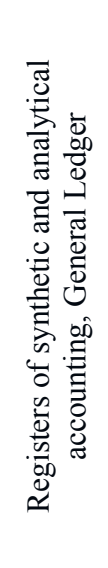 & 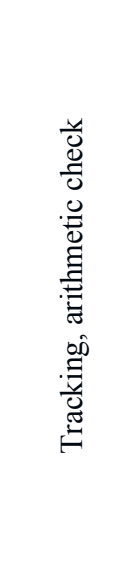 & $\begin{array}{l}0 \\
\underset{\infty}{\infty} \\
i \\
i n\end{array}$ & 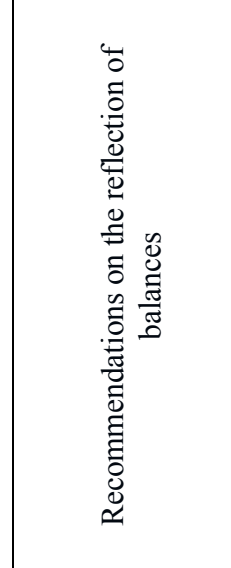 \\
\hline 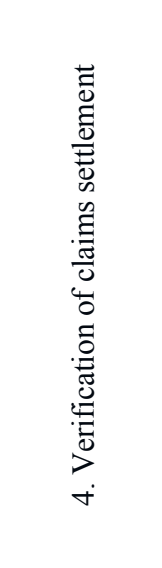 & 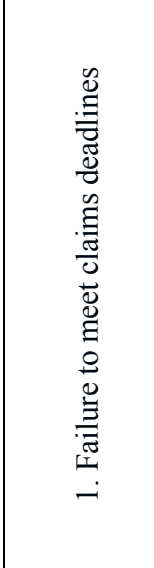 & 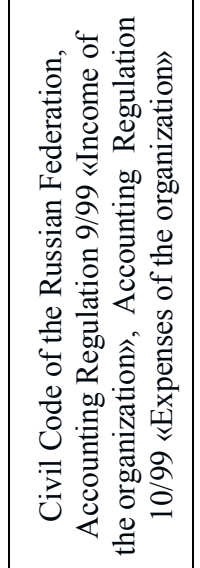 & 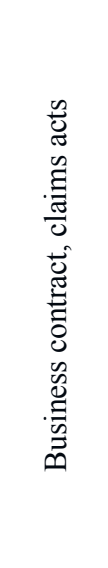 & 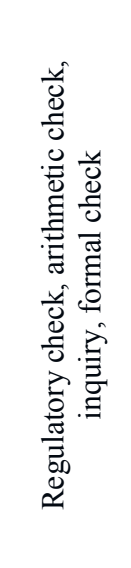 & ' & 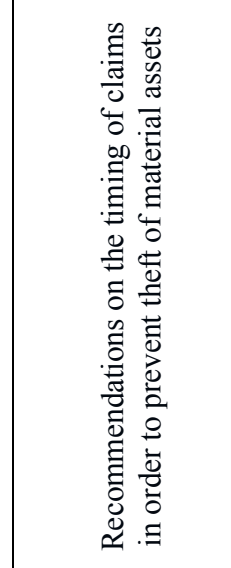 \\
\hline 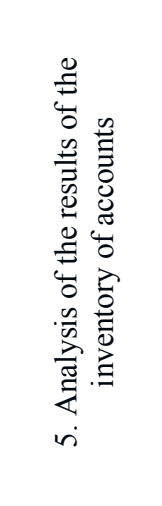 & 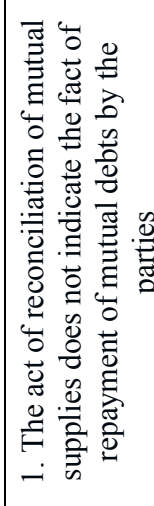 & 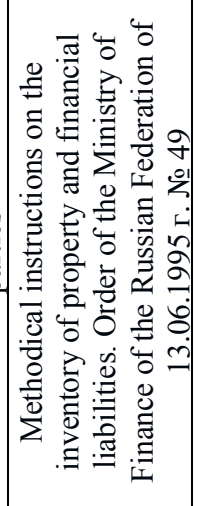 & 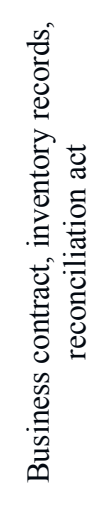 & 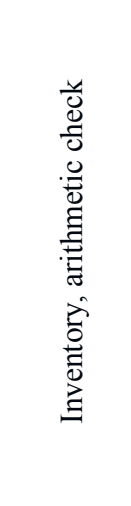 & 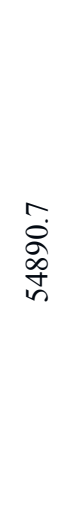 & 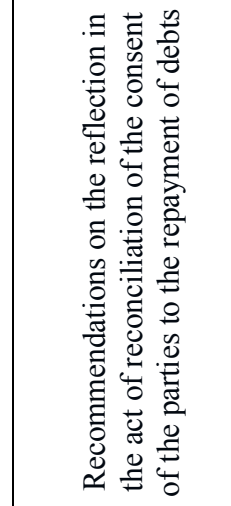 \\
\hline
\end{tabular}




\begin{tabular}{|c|c|c|c|c|c|c|}
\hline 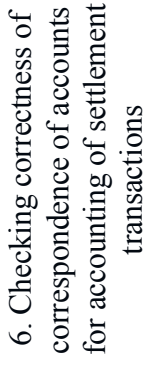 & 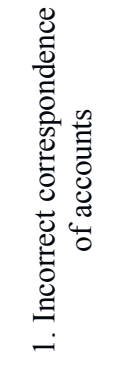 & 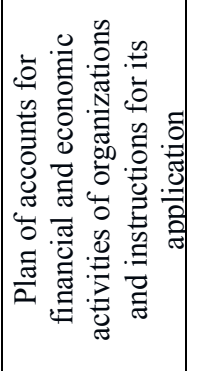 & 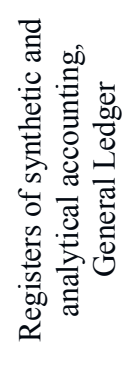 & 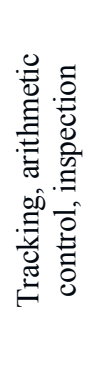 & 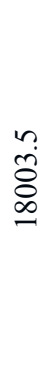 & 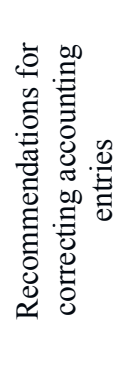 \\
\hline 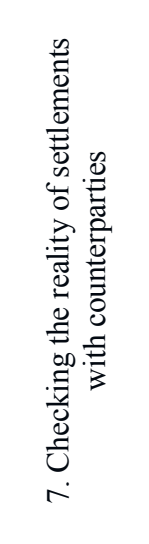 & 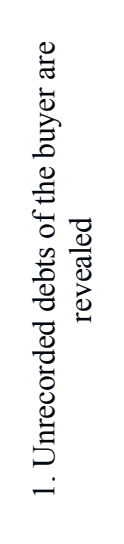 & 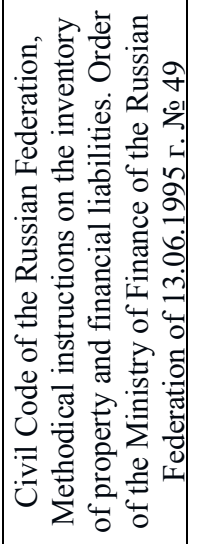 & 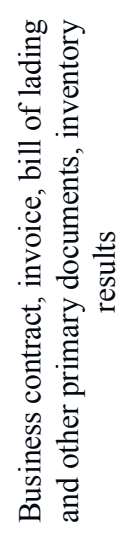 & 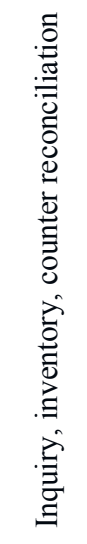 & 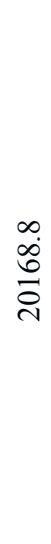 & 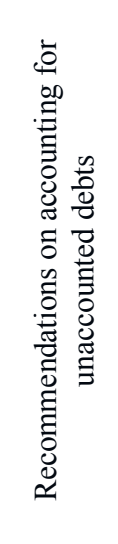 \\
\hline 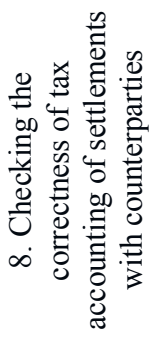 & 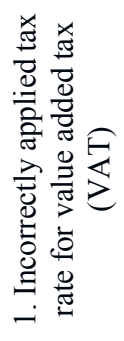 & 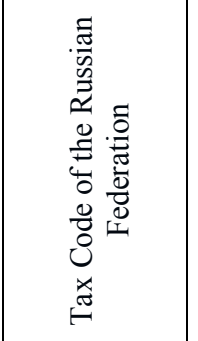 & 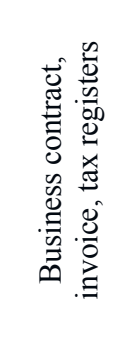 & 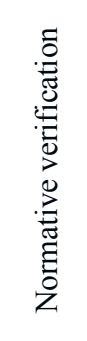 & $\begin{array}{l}\hat{\infty} \\
\stackrel{0}{\circ} \\
\vec{\gamma}\end{array}$ & 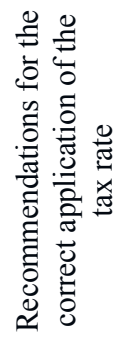 \\
\hline
\end{tabular}

\section{Discussion}

In conditions of economic crisis there is an objective necessity in optimization of accounts receivable with the purpose of acceleration of terms of its repayment. For this purpose it is necessary to analyze constantly the state of accounts receivable to carry out the rational policy concerning granting of loans and commodity credits. In practice of management of accounts receivable the following stages of decision-making by an economic agent about granting of commodity credits are distinguished: conditions of sale of production, rendering of services and performance of works and tools of commercial credit are defined; credit analysis of buyers is performed; decisions about granting of credit are made; mechanisms of return of funds are developed. Using this algorithm, internal controllers can assess the main indicators of receivables, and heads of internal control services can carry out effective planning of internal inspections.

Accounts payable management is inseparably connected with the analysis of accounts receivable and accounts payable ratio. Management of payables and receivables implies the establishment of contractual relations with suppliers and buyers, which ensure sufficient 
and timely receipt of funds. This requires information that characterizes the real state of payables and receivables and their turnover.

The level of accounts receivable and payable is influenced by external and internal factors (Fig. 8)

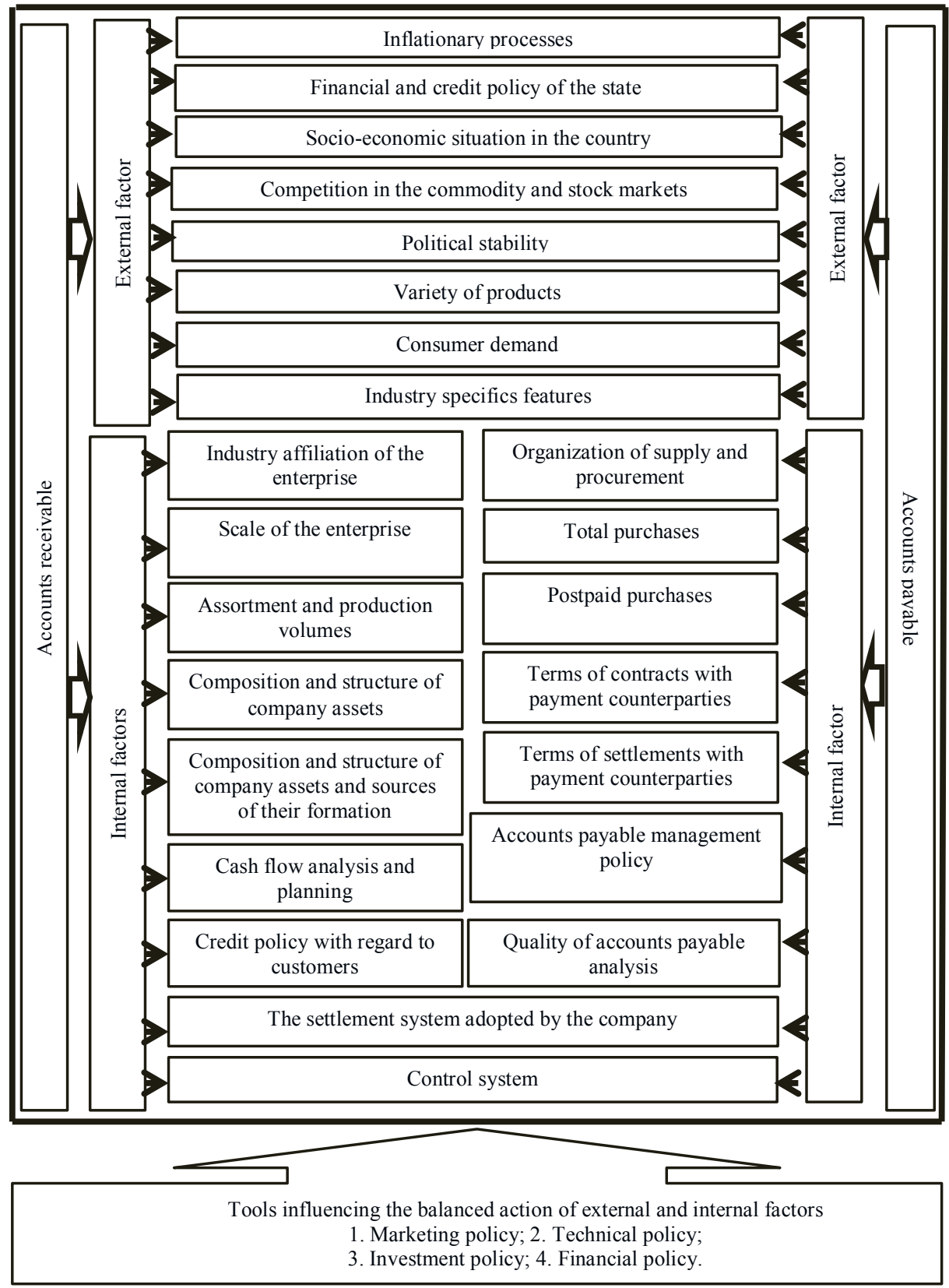

Fig. 8. Factors influencing the level of receivables and payables.

The analysis of the factors considered allows us to conclude that internal factors are relevant for the purposes of internal control, since they can not only be predicted, but also their influence on the amount and state of debts can be regulated. 
Besides it is necessary to note that some authors suggest to allocate the human factor as one of the internal factors influencing size of accounts receivable and payable. The personnel of the enterprise is the driving force, which activates assets, searches for financing sources and influences the size and condition of accounts receivable and payable. The most obvious influence of personnel on accounts receivable and payable can be traced on such factor as organization of control system. An efficiently organized control system makes it possible to timely identify the amount of accounts receivable and payable, the facts of the formation of overdue debt and the reasons for them.

The issues of rating assessment of the reliability of debtors in order to make management decisions regarding the provision of deferred payments for products sold, work performed, services rendered are of particular relevance.

Modern measures connected with stimulation of liquidation or partial repayment of accounts receivable should be considered in accordance with developed credit policy, which is based on credit rating of counterparts.

With an effectively designed credit policy regarding different groups of counterparties, it is possible to effectively manage the emerging accounts receivable and improve the financial condition of the enterprise. Carrying out the rating of debtors, it is possible to carry out a comparative analysis of customers and to determine counterparties for which there is a risk of non-repayment of debts.

The main purpose of credit rating is to provide the management of an economic entity with information about the reliability of potential debtors.

In practice, economic services use various methods of scoring, which allow, by analyzing the experience of interaction with the counterparty, to determine the degree of its reliability.

The reliability of the counterparty is evaluated on the basis of a system of key indicators. We propose to assess the reliability of the customer to use the following indicators: the time of joint work with the counterparty, the volume of transactions with the counterparty in the total volume of business transactions, the term of repayment of accounts receivable counterparty, prospective sales to the counterparty in the total volume of planned sales, profitability of counterparty, the share of overdue debt of counterparty in total overdue debts, the possibility of repayment of existing debts of counterparty, turnover ratio of accounts receivable

Comprehensive assessment of credibility of debtors is based on the application of scorerating assessment (Table 5).

Table 5. Rating assessment of counterparty reliability.

\begin{tabular}{|l|c|c|c|}
\hline \multicolumn{1}{|c|}{ Assessment elements } & \multicolumn{3}{|c|}{ Value levels } \\
\cline { 2 - 4 } & $\begin{array}{c}\text { High (3 } \\
\text { points) }\end{array}$ & $\begin{array}{c}\text { Average } \\
\text { (2 points) }\end{array}$ & $\begin{array}{c}\text { Low } \\
\text { (1 point) }\end{array}$ \\
\hline $\begin{array}{l}\text { 1. Time of joint work with the } \\
\text { counterparty. years }\end{array}$ & More 3 & $1-3$ & Less 1 \\
\hline $\begin{array}{l}\text { 2. Volume of transactions with the } \\
\text { counterparty in the total volume of } \\
\text { business transactions. \% }\end{array}$ & More 20 & $10-20$ & Less 10 \\
\hline $\begin{array}{l}\text { 3. Term of repayment of accounts } \\
\text { receivable by the counterparty. months }\end{array}$ & Until 1 & $1-3$ & More 3 \\
\hline $\begin{array}{l}\text { 4. Prospective volume of sales to the } \\
\text { counterparty in the total volume of } \\
\text { planned sales. \% }\end{array}$ & More 25 & $15-25$ & Less 15 \\
\hline $\begin{array}{l}\text { 5. Profitability of the counterparty. \% } \\
\text { 6. Share of overdue debt of the } \\
\text { counterparty in the total amount of } \\
\text { overdue debt. \% }\end{array}$ & More 50 & $25-50$ & Until 25 \\
\hline
\end{tabular}




\begin{tabular}{|l|c|c|c|}
\hline $\begin{array}{l}\text { 7. Probability of repayment of existing } \\
\text { debt by the counterparty. \% }\end{array}$ & $80-100$ & $50-80$ & Less 50 \\
\hline 8. Ratio of accounts receivable turnover & $0.75-1$ & $0.5-0.75$ & Less 0.5 \\
\hline 24-20 - high degree of reliability of the counterparty \\
\hline 19-14 - medium degree of reliability of the counterparty \\
\hline Less than 14 - low counterparty reliability \\
\hline
\end{tabular}

Based on the evaluation system, counterparties should be ranked according to the following categories of reliability: high, medium and low reliability of the counterparty (Table 6).

Table 6. Counterparties ranking by reliability categories.

\begin{tabular}{|c|c|c|c|c|c|c|c|c|c|}
\hline ن⿺辶卂 & 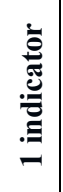 & 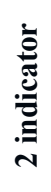 & 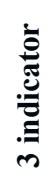 & 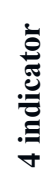 & 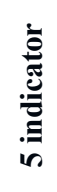 & 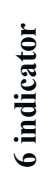 & 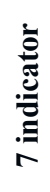 & 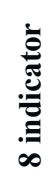 & हేّ \\
\hline$\overline{\mathrm{LLC}}\langle$ Kolos» & 3 & 3 & 3 & 2 & 2 & 2 & 3 & 3 & 21 \\
\hline LLC «Lada» & 1 & 1 & 2 & 2 & 1 & 2 & 2 & 2 & 13 \\
\hline LLC «Avangrad» & 3 & 2 & 2 & 2 & 2 & 3 & 2 & 2 & 18 \\
\hline JSC «Lotos» & 3 & 3 & 2 & 3 & 2 & 3 & 2 & 3 & 19 \\
\hline
\end{tabular}

The proposed rating assessment of counterparties will allow for their comparative analysis and grouping, as well as to identify those of them, who have a high probability of failure to repay the existing debt. The given technique can be widely used in development of credit policy in order to decrease the amount of doubtful debts and in consequence increase the efficiency of company`s activity.

\section{Conclusions}

Thus, the particularity of internal control of settlement transactions is due to the variety of regulatory and informational support of the verification. The proposed methodological support is based on a step-by-step verification of settlement transactions, which includes the following main stages: planning of verification; implementation of control procedures; registration of verification results. The proposed methodology identifies the areas of control, the regulatory framework and sources of information, the nature of verification and control procedures that are necessary to achieve the objectives and practical solutions to the objectives of the audit

In order to improve control procedures, working documents of internal control «Internal Control Program of Settlement Transactions», "Verification of the existence of an agreement with a separate counterparty», «Confirmation of the status of settlements with counterparties» were developed in the course of the study. «Internal Control Program for Settlement Transactions» is a detailed inspection instruction and quality control tool for the work of the internal controller. The working document «Verification of the availability of the agreement with a separate counterparty» can be used by the controller to identify errors arising in the preparation of the contract, as well as to determine the completeness and timeliness of the parties to fulfill their obligations. With the help of the working document "Confirmation of the status of settlements with counterparties» proposed in the course of the study and when conducting the control procedure - inquiry to counterparties - it is possible to identify cases of fraud and misstatement of data contained in the financial statements. 
In the course of the study, it was proposed in the process of internal control to carry out a point-rating assessment of the reliability of debtors, based on the use of a system of key indicators. The proposed rating assessment of counterparties will make it possible to carry out their comparative analysis and grouping, as well as to identify those of them with a high probability of non-repayment of existing debt. The presented methodology can be widely used in the development of credit policy in order to reduce the amount of doubtful debts and, as a consequence, increase the efficiency of the enterprise.

The implementation of the proposed recommendations in practical activities of the control services of the enterprises will increase the efficiency of the control measures.

\section{References}

1. F. Casalin, G. Pang, S. Maioli, T. Cao, International Journal of Production Economics 193, 148-159 (2017) https://doi.org/10.1016/j.ijpe.2017.07.010

2. Q. Wang, J. Wu, N. Zhao, Q. Zhu, Resources, Conservation and Recycling 145, 78-85 (2019) https://doi.org/10.1016/j.resconrec.2019.02.024

3. H. Nam, K. Uchida, Journal of Banking \& Finance 102, 116-137 (2019) https://doi.org/10.1016/j.jbankfin.2019.03.010

4. A. Zakirova, G. Klychova, G. Ostaev, E. Zaugarova, A. Nigmetzyanov, E. Zaharova, E3S Web of Conferences 164, 10009 (2020) https://doi.org/10.1051/e3sconf $/ 202016410009$

5. V.N. Azarskov, L.S. Zhiteckii, K.Yu. Solovchuk et al, IFAC-Papers On Line 50, 10154-10159 (2017) https://doi.org/10.1016/j.ifacol.2017.08.1762

6. Dz. Faizrakhmanov, A. Zakirova, G. Klychova, A. Yusupova, A. Klychova, E3S Web of Conferences 91, 06004 (2019) https://doi.org/10.1051/e3sconf/20199106004

7. A. Suhányiová, L. Suhányi, M. Mokrišová, J. Horváthová, Procedia Economics and Finance 34, 311-318 (2015) https://doi.org/10.1016/S2212-5671(15)01635-4

8. M. Edmonds, T. Miller, A. Savage, Journal of Accounting Education 47, 75-92 (2019) https://doi.org/10.1016/j.jaccedu.2019.04.001

9. R.P. Boisjoly, T.E. Conine, M.B. McDonald, Journal of Business Research 108, 1-8 (2020) https://doi.org/10.1016/j.jbusres.2019.09.025

10. W. Dbouk, L. Moussawi-Haidar, M.Y. Jaber, International Journal of Production Economics 230, 107888 (2020) https://doi.org/10.1016/j.ijpe.2020.107888

11. G. Klychova, A. Zakirova, S. Alibekov et al, Advances in Intelligent Systems and Computing 1258 AISC, 669-686 (2021) https://doi.org/10.1007/978-3-030-574505_58

12. J. Enqvist, M. Graham, J. Nikkinen, Research in International Business and Finance 32, 36-49 (2014) https://doi.org/10.1016/j.ribaf.2014.03.005

13. T.-Sh. Wang, Y.-M. Lin, H. Chang, International Review of Economics \& Finance 58, 312-329 (2018) https://doi.org/10.1016/j.iref.2018.04.003

14. J. Leontieva, E. Zaugarova, G. Klychova, A. Zakirova, A. Klychova, MATEC Web of Conferences 170, 01087 (2018) doi.org/10.1051/matecconf/201817001087

15. G. Klychova, A. Zakirova, R. Mannapova, K. Pinina, Y. Ryazanova, E3S Web of Conferences 110, 02075 (2019) doi.org/10.1051/e3sconf/201911002075

16. S.G. Mun, S. Jang, International Journal of Hospitality Management 48, 1-11 (2015) DOI: 10.1016/j.ijhm.2015.04.003 
17. P.G. Thacker, R.J. Witte, R. Menaker, Clinical Imaging. 64, 80-84 (2020) https://doi.org/10.1016/j.clinimag.2020.03.015

18. A. Zakirova, G. Klychova, R. Nurieva, A. Nigmetzyanov, E. Zaugarova, U. Raheem, Advances in Intelligent Systems and Computing 1259 AISC, 98-123 (2021) https://doi.org/10.1007/978-3-030-57453-6_10

19. M. Roussy, Critical Perspectives on Accounting 24, 550-571 (2013) https://doi.org/10.1016/j.cpa.2013.08.004

20. K. Chalmers, D. Hay, H. Khlif, Journal of Accounting Literature 42, 80-103 (2019) https://doi.org/10.1016/j.acclit.2018.03.002

21. J. Wang, K. Hooper, Critical Perspectives on Accounting 49, 18-30 (2017) https://doi.org/10.1016/j.cpa.2017.04.003

22. G.S. Klychova, A.R. Zakirova, E.R. Kamilova, International Business Management 10, 5254-5260 (2016) DOI: 10.3923/ibm.2016.5254.5260

23. M. Hanskamp-Sebregts, P.B. Robben, H. Wollersheim, M. Zegers, Health Policy 124, 216-223 (2020) https://doi.org/10.1016/j.healthpol.2019.11.013

24. A. Klychova, G. Klychova, A. Zakirova, R. Sungatullina, K. Mukhamedzyanov, E. Philippova, E3S Web of Conferences 110, 02072 (2019) doi.org/10.1051/e3sconf/201911002072

25. Y.-T. Chang, H. Chen, R.K. Cheng, W. Chi, Journal of Contemporary Accounting \& Economics 15, 1-19 (2019) https://doi.org/10.1016/j.jcae.2018.11.002

26. Y. Li, X. Li, E. Xiang, H.G. Djajadikerta, Journal of Contemporary Accounting \& Economics 16, 100210 (2020) https://doi.org/10.1016/j.jcae.2020.100210

27. Sh.-I. Chang, L.-M. Chang, J.-C. Liao, Information \& Management 57, 103335 (2020) https://doi.org/10.1016/j.im.2020.103335

28. D.B. Bryan, Advances in Accounting 36, 11-26 (2017) https://doi.org/10.1016/j.adiac.2016.09.005

29. E. Demirakos, The International Journal of Accounting 53, 253-254 (2018) https://doi.org/10.1016/j.intacc.2018.07.001

30. Schantl, S.F., Wagenhofer, A. Journal of Accounting and Public Policy 1, 106803 (2020) https://doi.org/10.1016/j.jaccpubpol.2020.106803

31. X.-D., Ji, W. Lu, W. Qu, Journal of Contemporary Accounting \& Economics 14, 266287 (2018) https://doi.org/10.1016/j.jcae.2018.07.002

32. W. Shu, Y. Chen, B. Lin, Y. Chen, China Journal of Accounting Research 11, 407-427 (2018) https://doi.org/10.1016/j.cjar.2018.09.002

33. H. Li, J. Dai, T. Gershberg, M.A. Vasarhely, International Journal of Accounting Information Systems 28, 59-76 (2018) https://doi.org/10.1016/j.accinf.2017.12.005 